\title{
Meningkatkan Aktivitas Dan Hasil Belajar Siswa Dalam Mata Pelajaran Keterampilan Melalui Metode Keterampilan Meniru Obyek Gambar Pada Siswa Kelas VIII SMP Negeri 3 Palopo
}

\author{
Hadiana \\ SMP Negeri 3 Palopo \\ $+62812-4299-5862$
}

Abstrak

Penelitian ini adalah penelitian tindakan kelas yang bertujuan untuk mengetahui peningkatan prestasi belajar pada mata pelajaran keterampilan (seni rupa) menggunakan melalui metode keterampilan meniru obyek gambar pada siswa kelas VIII SMP Negeri 3 Palopo Kota Palopo. Berdasarkan hasil pengamatan terhadap siswa dalam diskusi dan menyelesaikan tugas-tugasnya, tampak bahwa metode meniru belajar mandiri dalam mengerjakan tugas-tugas lebih menggairahkan keinginan siswa dalam melakukan diskusi. Dalam mengikuti pembelajaran, siswa lebih senang dan menarik karena mereka harus tanpa berpikir lebih dahulu baru dapat mengerjakan tugas dan seperti dengan rela untuk mengerjakan tugas dalam menyimak yang secara teori kurang mereka mengerti. Berdasarkan data yang diperoleh, dapat dikatakan bahwa penelitian ini berhasil karena nilai siswa mengalami peningkatan. Sesuai dengan hasil analisis, nilai rata-rata kelas mengalami peningkatan dari 74,06 menjadi 90,75 , daya serap mengalami peningkatan dari $74,06 \%$ menjadi $90,75 \%$ dan ketuntasan terjadi secara maksimal sebesar $100 \%$ pada siklus I dan II.

Kata Kunci: keterampilan, gambar, meniru obyek

\section{Pendahuluan}

Sekolah Menengah Pertama (SMP) merupakan masa sekolah untuk menggali lebih dalam mengenai potensi besar siswa atau peserta didik ada dimana. Namun peserta didik tentu tidak bisa menemukan potensi yang ada dalam dirinya, apabila dilakukannya sendiri. Perlu ada bantuan ataupun rangsangan (stimulus) dari guru / pelaku didik. Hal ini adalah fakta. Banyak peserta didik yang tidak tahu kemana harus melangkah setelah tuntas belajar di SMP karena semasa SMP, peserta didik merasa ini hanyalah rutinitas. Padahal, dengan sedikit campur tangan guru melalui variasi metode belajar, peserta didik mampu mengenal kemampuan besar yang ada dalam dirinya.

Seperti pelajaran lain, kalau metode belajar guru yang diterapkan tepat dan kedisiplinan siswa dalam belajar juga konsisten, maka semua pelajaran, apapun itu, pasti bisa dipahami. Yang menjadi masalah umum dalam dunia pendidikan khususnya di SMP, masih banyak guru yang tidak peduli dengan metode yang terapkannya, apakah hasil belajar siswa mampu membekas di benak siswa atau tidak.

Tahun pelajaran 2014/2015 hasil prestasi belajar mata pelajaran keterampilan pada siswa kelas VIII SMP Negeri 3 Palopo Kota Palopo belum mencapai nilai rata-rata yang maksimal, nilai rata-rata yang diperoleh yaitu skor 75,00 kategori tinggi sedangkan yang diharapkan 
adalah nilai dalam kategori sangat tinggi yaitu skor 85 - 100. Kalau dilihat kembali, maka beberapa faktor bisa menjadi penyebab masalah itu, di antaranya: (1) siswa beranggapan pelajaran keterampilan adalah pelajaran sampingan, tidak lebih penting dibandingkan pelajaran seperti matematika, bahasa indonesia dan bahasa inggris, (2) metode belajar guru yang diterapkan masih terbilang konvensional yaitu memberikan bahan untuk disalin, metode ceramah, dan pemberian tugas yang sulit untuk dipantau obyektivitasnya, (3) kurangnya media pembelajaran seperti buku bacaan yang dijadikan rujukan belajar siswa.

\section{Pemberian Tugas dalam Pelajaran Keterampilan}

Salah satu strategi belajar dasar kompetensi kejuruan yang baik adalah memperbesar frekuensi pengulangan materi dengan memperbanyak latihan soal-soal di rumah sehingga menjadi suatu keterampilan yang dapat melatih diri dan mendayagunakan pikiran. Tugas yang diberikan tidak hanya berupa latihan soal-soal tetapi dapat bermacam-macam bentuknya yang pada akhirnya bertujuan untuk meningkatkan prestasi belajar siswa. Menurut Nasution ( 1986 ) tugas yang diberikan kepada siswa dapat berupa:

a. Pekerjaan rumah sebagai pembelajaran secara mandiri, misalnya mempelajari satu bab dari buku pelajaran.

b. Pekerjaan rumah sebagai latihan misalnya menyelesaikan soal-soal dari materi yang telah diajarkan.

c. Pekerjaan rumah sebagai proyek yakni mengumpulkan sejumlah bahan yang berhubungan dengan materi yang akan atau lelah dipelajari.

Teknik pemberian tugas digunakan dengan tujuan agar siswa dapat melaksanakan latihanlatihan selama proses pembelajaran serta dalam mempelajari materi lebih terintegrasi. Disamping itu mengerjakan tugas merangsang siswa untuk belajar lebih baik, berani bertanggung jawab, keterampilan berpikir, dan keterampilan memecahkan masalah sesuai dengan aturan yang tersedia. Tugas ini juga membuat siswa terbiasa untuk mencari dan mengelolah sendiri tugas yang diberikan serta metode ini dapat mengencangkan kualitas siswa.

Dalam proses belajar mengajar akan lebih baik bila siswa secara aktif terlibat dalam proses penemuan pertalian-pertalian atau hubungan dari informasi yang diperoleh. Dengan adanya aktivitas belajar ini akan menghasilkan kemampuan belajar dan peningkatan pengetahuan. Proses belajar tidak mungkin akan berhasil tanpa adanya aktivitas belajar itu sendiri. Itulah sebabnya aktivitas merupakan prinsip yang penting dalam interaksi belajar mengajar.

Minat erat sekali hubungannya dengan suka atau tidak suka, tertarik atau tidak tertarik dan senang atau tidak senang. Minat tidak tercetus dengan sendirinya, tetapi sesuatu yang terwujud disebabkan oleh pengaruh-pengaruh tertentu seperti penguasaan terhadap materi pelajaran. Perasaan senang akan menimbulkan minat, yang diperkuat lagi oleh sikap yang positif. Yang jelas perasaan tidak senang akan menghambat dalam belajar, karena tidak melahirkan sikap positif dan tidak menunjang minat belajar siswa. Penyebab turunnya minat belajar siswa antara lain karena kurangnya motivasi dalam diri siswa itu sendiri.

Turunnya minat belajar ini akan berdampak negatif pada hasil belajar, karena sesuatu yang dilakukan tanpa dilandasi niat, kemauan dan usaha yang keras hanya akan sia-sia dan memberikan hasil yang tidak maksimal. Dengan demikian, aktivitas dan minat belajar siswa menentukan tingkat keberhasilan siswa dalam pembelajaran. 
Pemberian tugas merupakan salah satu metode yang tepat untuk menumbuhkan minat siswa dalam pembelajaran. Dengan memberikan tugas kepada siswa, kemudian diadakan evaluasi terhadap hasil pekerjaan dari tugas tersebut, maka hal itu akan memberikan rasa kepercayaan diri siswa dalam mengerjakan tugas selanjutnya yang tentunya berkaitan dengan tugas sebelumnya.

Selama ini metode pemberian tugas sudah diterapkan tetapi belum mencapai hasil yang maksimal, untuk mencapai apa yang diharapkan maka diperlukan penelitian guna untuk memperbaiki yang masih dianggap belum mencapai hasil yang maksimal dengan demikian maka hasil akhir akan terjadi peningkatan. Untuk itu, penelitian ini bertujuan untuk mengetahui peningkatan prestasi belajar pada mata pelajaran Keterampilan (Seni Rupa) Menggunakan Metode Pemberian Tugas.

\section{Metode Penelitian}

Penelitian tindakan kelas (PTK) ini dilaksanakan di SMP Negeri 3 Palopo Kota Palopo. Jadwal pelaksanaan penelitian ini adalah pada semester genap tahun pelajaran 2017/2018 (antara bulan Mei s.d. Agustus)

Kelompok sasaran yang menjadi subyek penelitian adalah semua siswa kelas VIII SMP Negeri 3 Palopo Kota Palopo semester genap tahun pelajaran 2017/ 2018 dengan jumlah siswa 32 orang. Obyek penelitian ini adalah model pembelajaran pemberian tugas. Karakteristik dari subyek penelitian yaitu sebagian besar siswa hanya mengerjakan tugas tanpa terencana dengan baik.

Jenis data yang dikumpulkan dalam penelitian ini yaitu data hasil belajar siswa. Berdasarkan jenis data yang dikumpulkan, maka sumber datanya adalah siswa, dalam hal ini semua siswa kelas VIII.A SMP Negeri 3 Palopo Kota Palopo semester genap tahun pelajaran 2017/2018 yang berjumlah 32 orang.

\section{Rancangan Penelitian}

Penelitian ini terdiri atas 2 siklus, masing-masing siklus terdiri dari empat tahap. Secara operasional prosedur penelitian diuraikan dalam bagan berikut:

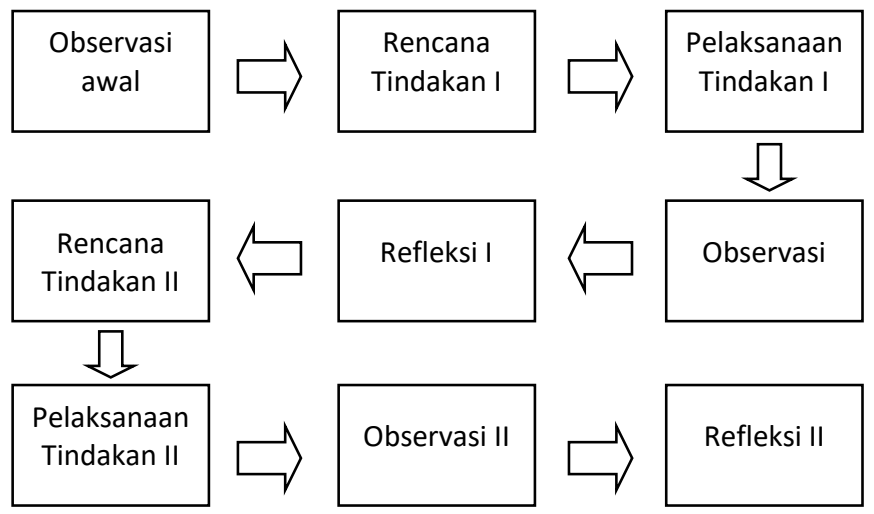

Gambar 1. Tahap-tahap Penelitian Tindakan Kelas

\section{Perencanaan}

Sesuai dengan refleksi awal maka ada beberapa hal yang perlu dipersiapkan dalam penelitian ini sebagai berikut. Kegiatan-kegiatan yang dilakukan dalam tahap perencanaan adalah sebagai berikut. 
1 Mengidentifikasi permasalahan berdasarkan hasil observasi awal.

2 Menentukan materi.

3 Menyusun rencana pelaksanaan pembelajaran (RPP) lengkap dengan materi pembelajaran.

4 Membuat lembar observasi keterlaksanaan kegiatan belajar mengajar untuk mengetahui proses pembelajaran.

\section{Tindakan}

Tahap ini adalah melaksanakan tindakan sesuai dengan perencanaan tindakan yang telah dipersiapkan untuk diterapkan dalam proses pembelajaran. Pelaksanaan tindakan dalam penelitian tindakan kelas ini hendaknya didasarkan atas pertimbangan teoritik dan empirik agar hasil yang diperoleh optimal. Selain itu pelaksanaan tindakan dilakukan sejalan dengan laju perkembangan pelaksanaan kurikulum dan kegiatan belajar mengajar di kelas.

Skenario pembelajaran siklus II disusun sesuai dengan hasil revisi pembelajaran siklus I, walaupun demikian langkah-langkahnya tetap mengikuti kegiatan pada skenario pembelajaran seperti pada tabel di atas dengan ditambah beberapa modifikasi apabila ternyata dalam siklus I terdapat kelemahan-kelemahan dalam pelaksanaan pembelajaran.

\section{Observasi/ Evaluasi}

Kegiatan observasi dalam penelitian tindakan kelas dapat disejajarkan kedudukannya dengan pengumpulan data dalam penelitian formal. Observasi dilakukan dari awal hingga akhir proses pembelajaran. Observasi bertujuan untuk mendapatkan data tentang situasi terkini proses pembelajaran, aktivitas belajar siswa, hasil belajar serta mengetahui kesesuaian antara pelaksanaan pembelajaran di kelas dengan rencana pelaksanaan pembelajaran yang telah disusun.

\section{Refleksi}

Refleksi merupakan kegiatan analisis, sintesis, interpretasi, dan eksplanasi terhadap semua informasi yang diperoleh dari pelaksanaan tindakan. Pada tahap ini dilakukan diskusi antara guru bidang studi, observer, dan peneliti untuk mengetahui hal-hal yang terjadi sebelum, selama, dan sesudah proses pembelajaran berlangsung. Data dan identifikasi permasalahan serta refleksi pada tindakan I dijadikan dasar untuk menyusun tindakan pada siklus II.

\section{Hasil Penelitian \& Pembahasan}

Siswa kelas VIII SMP Negeri 3 Palopo Kota Palopo adalah siswa yang tergolong kelas dengan kemampuan sedang dalam beberapa mata pelajaran khususnya pelajaran produktif sehingga dalam proses proses pembelajaran memerlukan upaya-upaya khusus dalam menanganinya. Hasil belajar yang paling menonjol mengungkapkan bahwa siswa sulit memahami pelajaran khususnya dalam mendeskripsikannya. Siswa cenderung sulit memahami konsep pelajaran sehingga hasil belajar yang diperoleh sangat rendah.

Untuk mendapat data akurat tentang kondisi awal siswa, peneliti mengadakan tes awal. Sebelum pelaksanaan tes awal, dilaksanakan proses pembelajaran secara konvensional yaitu dengan menggunakan metode ceramah ataupun dengan kerja kelompok namun kegiatannya kurang terstruktur terhadap subjek penelitian yaitu siswa kelas VIII. SMP Negeri 3 Palopo Kota Palopo dengan jumlah siswa 32 orang. Dengan proses pembelajaran seperti itu, tampak siswa kurang antusias dan kurang aktif dalam belajar. 


\section{Hasil Tes Awal}

Hasil pelaksanaan tes awal, diperoleh data bahwa kemampuan siswa mengambar obyek tiga dimensi pada mata pelajaran keterampilan (seni rupa) masih tergolong rendah. Untuk mengetahui ketuntasan belajar siswa secara individual, data dibandingkan dengan nilai KKM (Kriteria Ketuntasan Minimal) yang berlakukan di kelas VIII SMP Negeri 3 Palopo Kota Palopo yaitu dengan KKM 70 untuk mata pelajaran produktif.

Secara rinci dapat diuraikan bahwa dari 32 orang siswa kelas VIIIA yang hadir pada pelaksanaan tes awal hadir 30 orang $(31,25 \%)$ yang tuntas dan22 orang $(68,75 \%)$ belum tuntas. Nilai terendah 60 (frekuensiya 6 orang), nilai terendah 30 diperoleh 1 orang tertinggi 80 (frekuensi 2 orang) dengan daya serap mencapai 56,88\%. Secara singkat data tes awal disampaikan pada tabel.

Tabel 1. Data Tes Awal Hasil Belajar

\begin{tabular}{|c|c|c|c|c|c|c|}
\hline & No. & $\begin{array}{l}\text { Nilai } \\
\text { Tes }\end{array}$ & Frekuensi & $\begin{array}{r}\text { Jumlah } \\
\text { Nilai }\end{array}$ & No. Absen & Ket \\
\hline & 1 & 30 & 1 & 30 & 23 & BT \\
\hline & 2 & 35 & 0 & & & \\
\hline & 3 & 40 & 4 & 160 & $3,9,14,24$ & BT \\
\hline & 4 & 45 & 0 & & & \\
\hline & 5 & 50 & 11 & 550 & $\begin{array}{l}2,8,10,11,12,13 \\
15,20,28,30,32\end{array}$ & BT \\
\hline & 6 & 55 & 0 & & & \\
\hline & 7 & 60 & 6 & 360 & $16,18,19,25,27,29$ & BT \\
\hline & 8 & 65 & 0 & & & \\
\hline & 9 & 70 & 8 & 560 & $\begin{array}{l}1,5,6,17,21,22 \\
26,31\end{array}$ & $\mathrm{~T}$ \\
\hline & 10 & 80 & 2 & 160 & 4,7 & \\
\hline & & $\mathrm{N}$ & 32 & & & \\
\hline & $\sum x$ & & & 1820 & & \\
\hline & Rata & & & 56,88 & & \\
\hline & Day & & & $56,88 \%$ & & \\
\hline & Ketu & & & $31,25 \%$ & & \\
\hline Keterangan : & & & & & & \\
\hline KKM & $=70$ & & & & & \\
\hline BT & = Belum & & & & & \\
\hline $\mathrm{T}$ & $=$ Tuntas & & & & & \\
\hline
\end{tabular}

\section{Deskripsi Siklus I}

Tindakan Siklus I dilaksanakan sebanyak 3 kali pertemuan. Pertemuan I berlangsung pada hari Senin, 8 Juni 2010 dan pertemuan II pada hari sabtu 20 Juni 2017 dan pertemuan III pada hari Senin 22 Juni 2017. Semua siswa Kelas VIII hadir baik pada pertemuan I maupun II. Pada siklus ini diimplementasikan rencana tindakan yang diuraikan pada bagian berikut ini:

\section{Pertemuan I}

Pertemuan I siklus I dilaksanakan pada hari Kamis, 4 Juni 2017 jam pelajaran ke 3 - 6 . Semua siswa kelas VIII hadir pada pertemuan ini.

Mengawali kegiatan, guru membuka pelajaran dengan mengucapkan salam dan mengabsen siswa serta menciptakan suasana kondusif dalam kelas agar tercipta suasana kelas yang tidak tegang. Setelah itu, guru kemudian memberikan apersepsi untuk memancing motivasi siswa untuk belajar dengan bertanya kepada seputar materi yang akan disampaikan pads pertemuan tersebut. Setelah siswa nampak sudah bisa menjawab pertanyaan sebagai bahan apersepsi, 
peneliti menganggap bahwa pelajaran sudah bisa dilanjutkan. Sebelum melanjutkan ke pelajaran, guru terlebih dahulu mengelompokkan siswa ke dalam beberapa kelompok. Setiap kelompok terdiri dari 5-6 orang siswa yang heterogen baik kemampuan akademiknya dan dengan segera siswa menuju kelompok masing-masing. Walaupun pembagian kelompok sudah diatur oleh guru, namun beberapa orang siswa masih ribut karena ingin satu kelompok dengan teman dekatnya. Menanggapi masalah ini, guru memberikan pengarahan kepada siswa agar tidak memilih-milih teman dalam belajar karena semua teman sama. Akhirnya situasi kelas yang ribut dapat dikendalikan oleh guru dan akhirnya siswa mau berkelompok dengan teman yang lain.

Setelah membagi kelompok, guru mulai menjelaskan mengenai isi materi yaitu tugas membuat skestas gambar kubus dan silindris dengan teknik yang benar dan penerapan perspektif, setelah siswa memahami, guru kemudian membagikan tugas dalam bentuk LKS kepada setiap kelompok. Masing-masing kelompok diberikan tugas yang sama agar nanti memperoleh persepsi yang sama dan mendapat kesimpulan yang kaya akan pengetahuan. Setelah membagikan tugas kepada masing-masing kelompok, guru kemudian meminta siswa untuk mengerjakannya dalam waktu 45 menit. Serentak semua siswa mengerjakan tugasnya, namun beberapa siswa yang agak nakal nampak tidak serius mengerjakan tugas dengan kelompoknya. Siswa tersebut kelihatan hanya memanfaatkan teman yang pintar saja untuk mengerjakan tugas. Mengamati keadaan seperti itu, guru kemudian menghampiri siswa yang agak nakal tersebut dan menanyakan kenapa tidak ikut mengerjakan tugas. Siswa tersebut tidak bisa menjawab dan hanya menggeleng-gelengkan kepala saja. Karena siswa tidak mau mengaku, maka guru membiarkan saja. Namun beberapa menit kemudian siswa tersebut tidak berani lagi menggangu temanya. Bahkan siswa tersebut berpura-pura membantu temannya.

Pada saat pelaksanaan tugas guru berkeliling mengawasi siswa berdiskusi kelompok dan apabila ada siswa yang membuat keributan, dengan segera guru menghampirinya dan menanyakan apakah ada permasalahan yang dialami. Dalam kegiatan ini nampaknya banyak siswa yang memanfaatkan guru untuk bertanya terhadap masalah yang tidak bisa dipecahkan dalam kelompok, Guru pun membantu siswa memberikan masukan.

Setelah dirasakan cukup lama siswa belum selesai berdiskusi, maka guru membatasi waktu diskusi, guru melanjutkan kegiatan dengan menugaskan perwakilan masing-masing anggota kelompok untuk melaporkan hasil diskusi. Nampaknya setelah diberikan perintah untuk melaporkan hasil diskusi, siswa masih saling tunjuk dengan teman sekelompoknya untuk mewakili maju kedepan mempresentasikan hasil diskusinya. Melihat situasi tersebut, guru menjelaskan kepada siswa bahwa siswa yang mau presentasi, akan mendapat nilai bonus demikian juga siswa yang aktif dalam bertanya dan menjawab pertanyaan nantinya akan diberikan nilai bonus. Dengan memberikan penjelasan seperti itu, akhinya siswa berlombalomba minta untuk maju mempresentasikan hasil kerja kelompoknya.

Dalam kegiatan diskusi, siswa juga berlomba-lomba untuk bertanya kepada kelompok penyaji. Akhirnya guru pun membatasi setiap kelompok agar mengajarkan satu pertanyaan saja kepada kelompok yang presentasi. Dalam kegiatan ini, siswa nampak aktif dalam berdiskusi. Mengakhiri kegiatan diskusi, peneliti tidak lupa untuk meluruskan pendapatpendapat siswa yang masih keliru.

Sebelum mengakhiri pelajaran, guru kembali menugaskan siswa untuk membuat kesimpulan hasil diskusi dengan anggota kelompok masing-masing dan setelah membuat kesimpulan, guru kembali menugaskan untuk mengumpulkan kesimpulan yang sudah dibuat oleh masing-masing kelompok. 


\section{Pertemuan /I}

Pertemuan II siklus I dilaksanakan pada hari Senin, 15 Juni 2010 jam pelajaran ke 3 - 6 . Semua siswa kelas hadir pada pertemuan ini.

Mengawali kegiatan, guru membuka pelajaran dengan mengucapkan salam dan mengabsen siswa serta menciptakan suasana kondusif dalam kelas agar tercipta suasana kelas yang tidak tegang. Setelah itu, guru kemudian mengajukan apersepsi untuk memancing motivasi siswa dan untuk mengerjakan tugas yang diberikan agar dapat tercapai apa yang diinginkan. Guru tidak lupa mengingatkan prosedur pembelajaran yang akan digunakan pada proses pembelajaran sehingga siswa bisa melaksanakan pembelajaran sesuai dengan yang telah direncanakan. Sebelum memberikan tugas guru menjelaskan sedikit mengenai pokok materi yang akan dibahas.

Setelah guru menjelaskan materi pokok, guru mulai membagikan tugas kepada setiap kelompok. Masing-masing kelompok diberikan tugas yang sama, kegiatan ini dilakukan sama seperti pada pertemuan I. Setelah membagikan tugas kepada masing-masing kelompok, guru kemudian meminta siswa untuk mengerjakannya dalam waktu 20 menit. Pada pertemuan I dalam diskusi menggunakan waktu 25 menit namun pada pertemuan II siswa hanya diberikan waktu 20 menit supaya waktu untuk presentasi lebih banyak dan siswa bisa lebih banyak membahas pelajaran. Serentak semua siswa mengerjakan tugasnya dengan tertib.

Pada saat pelaksanaan tugas guru berkeliling mengawasi siswa berdiskusi kelompok dan apabila ada siswa yang membuat keributan, dengan segera guru menghampirinya dan menanyakan apakah ada permasalahan yang dialami. Dalam kegiatan ini nampaknya banyak siswa yang memanfaatkan guru untuk bertanya terhadap masalah yang tidak bisa dipecahkan dalam kelompok. Guru pun membantu siswa memberikan masukan.

Setelah siswa selesai mengadakan diskusi, kemudian guru melanjutkan kegiatan dengan menugaskan perwakilan masing-masing anggota kelompok untuk melaporkan hasil diskusi. Dalam pertemuan II, siswa tidak lagi saling tunjuk dengan temannya untuk membacakan hasil diskusi kelompoknya. Semua siswa masih mengingat apa yang dikatakan guru pada pertemuan I sehingga setiap siswa berusaha untuk berlomba-lomba mengajukan pertanyaan dan menjawab pertanyaan. Hingga akhirnya semua kelompok sudah mendapat giliran untuk mempresentasikan hasil diskusi kelompoknya. Mengakhiri kegiatan diskusi, guru tidak lupa memberikan penegasan kembali tentang materi pelajaran yang sudah dibahas lebih banyak oleh siswa, guru hanya meluruskan pendapat-pendapat siswa yang masih keliru.

Sebelum mengakhiri pelajaran, guru kembali menugaskan siswa untuk membuat kesimpulan hasil diskusi dengan anggota kelompok masing-masing dan setelah membuat kesimpulan, guru kembali menugaskan untuk mengumpulkan kesimpulan yang sudah dibuat oleh masing-masing kelompok karena akan diberikan penilaian oleh guru.

Guru juga tidak lupa mengingatkan kepada siswa untuk belajar di rumah mengenai materi pada pertemuan sebelumnya dan materi sekarang karena pada pertemuan berikutnya akan diadakan tes akhir siklus I. Kemudian guru menutup pelajaran dengan mengucapkan salam dan siswa dipersilakan untuk istirahat.

\section{Pertemuan III}

Pertemuan III siklus I dilaksanakan pada hari Senin, 23 Juni 2017 jam pelajaran ke 3 - 6 . Semua siswa kelas VIII hadir pada pertemuan ini. 
Mengawali pertemuan guru mengabsen siswa, mempersiapkan mereka mengikuti pembelajaran, selanjutnya bertanya tentang tugas pada pertemuan sebelumnya. Setelah bertanya tentang kesiapan siswa untuk mengikuti tes akhir, guru pun melanjutkan kegiatan dengan menilai hasil belajar siswa secara individu dengan membagikan tes formatif. Sebagian besar siswa dalam mengerjakan tes nampak serius, namun ada beberapa orang siswa masih meminta jawaban kepada teman.

Mengakhiri kegiatan penilaian, guru memberikan kesan-kesan selama siswa mengikuti pembelajaran pada siklus I baik itu pada kegiatan pembelajaran maupun kegiatan pada saat pelaksanaan tes. Setelah siswa memahami apa yang disampaikan oleh guru, guru kemudian menutup pelajaran dengan mengucapkan salam.

\section{Hasil Tindakan Siklus I}

Hasil tes akhir siklus I menunjukkan bahwa kemampuan siswa dalam tes hasilnya mengalami peningkatan. Hasil tes akhir menunjukkan bahwa siswa yang belum tuntas dalam kompetensi dasar tersebut berkurang. Walaupun sudah ada peningkatan, nilai yang diperoleh siswa masih tergolong sedang. Secara rinci hasil tes akhir pada siklus I diuraikan pada tabel berikut ini.

Tabel 2. Data Tes Hasil Belajar Siswa pada Siklus I

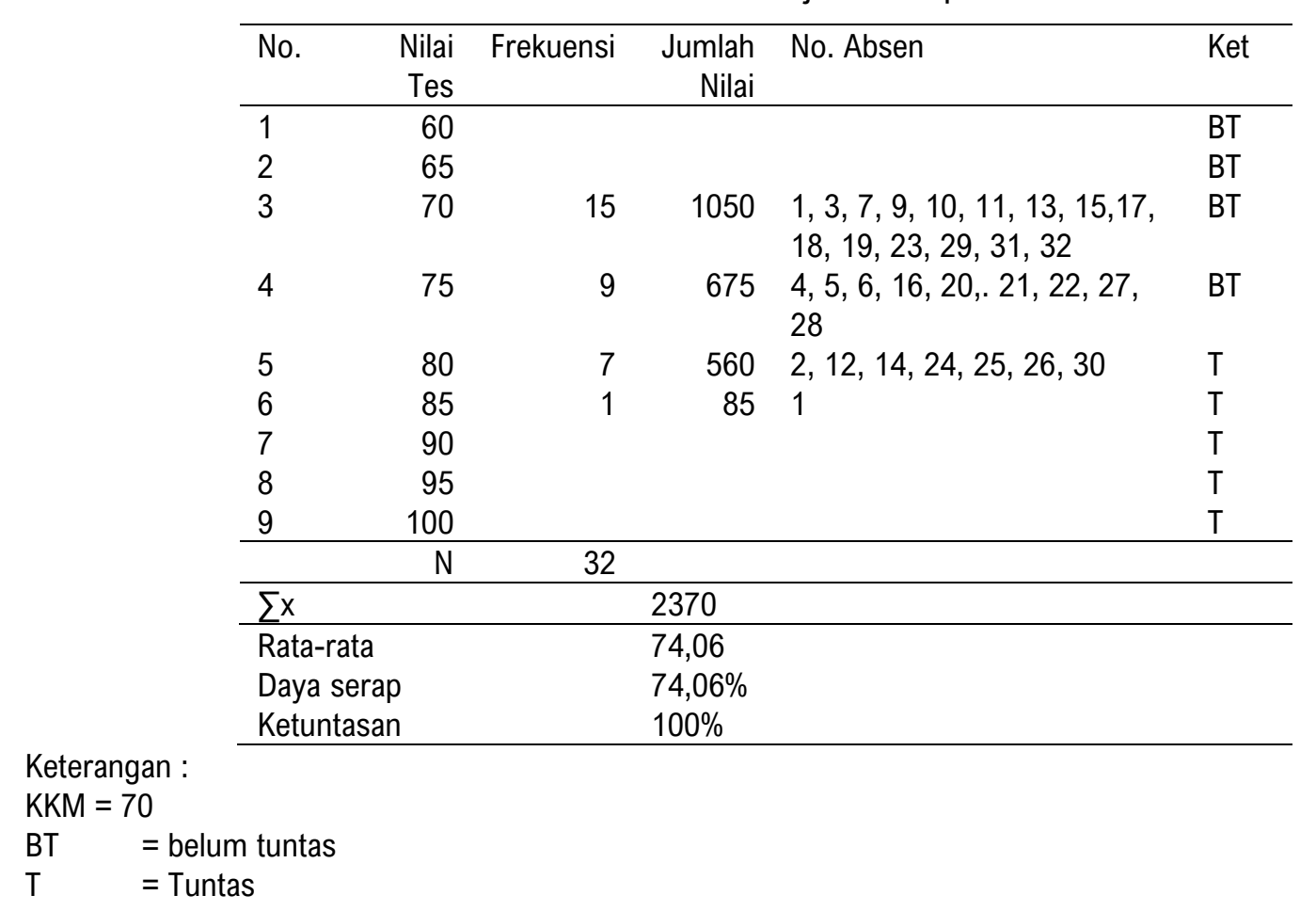

Secara klasikal ketuntasan belajar siswa kelas VIII SMP Negeri 3 Palopo Kota Palopo pada siklus I adalah $100 \%$. Hal ini menunjukkan bahwa sudah mencapai kriteria keberhasilan yaitu dengan ketuntasan minimal 70\%. Rata-rata hasil belajar siswa secara klasikal, 74,06 dan sudah mencapai hasil yang diharapkan yaitu dengan KKM 70. Daya serap siswa mencapai 74,06 yang berada pada kategori sedang dan belum mencapai hasil yang diharapkan yaitu minimal $70 \%$ (berdasarkan tabel konversi). Hasil belajar yang dicapai oleh siswa bisa dikatakan belum optimal. 


\section{Refleksi Siklus I}

Berdasarkan hasil pengamatan guru mengenai aktivitas belajar siswa, maka aktivitas belajar siswa perlu ditingkatkan lagi karena belum semua siswa terlibat aktif dalam diskusi. Dari hasil akhir siklus I, maka dalam refleksi diputuskan untuk melakukan tindakan siklus II. Dalam tindakan siklus II, peneliti ingin mengetahui apakah jika model pembelajaran ini diterapkan sekali lagi apakah hasil belajar siswa akan tetap mengalami peningkatan atau sebaliknya. Upaya yang dilakukan pada siklus II yaitu dengan mengoptimalkan proses pembelajaran dengan metode seperti itu. Kekeliruan-kekeliruan yang dilakukan pada siklus I diupayakan untuk diminimalisasai pada siklus II.

\section{Deskripsi Siklus II}

Tindakan siklus II dilalpanakan sebanyak 3 kali pertemuan. Pertemuan I berlangsung pada hari Senin, 8 Juli 2017 dan pertemuan II pada hari Senin 15 Juli 2017 dan Pertemuan III pada hari Senin 22 Juli 2017. Semua siswa kelas VIII hadir baik pada pertemuan I, II, maupun III. Pada siklus ini diimplementasikan rencana tindakan yang diuraikan pada bagian berikut ini.

\section{Pertemuan I}

Pertemuan I siklus II dilaksanakan pada hari Senin, 8 Juli 2017 jam pelajaran ke 3-6. Semua siswa kelas VIII hadir pada pertemuan ini. Kegiatan pembelajaran yang dilakukan pada pertemuan I siklus II ini sama seperti pada siklus I hanya saja dalam siklus II ada beberapa langkah pembelajaran yang dimodifikasi sebagai hasil refleksi pada siklus I.

Pada awal pertemuan siklus II, ketika masuk ke ruangan guru mulai membuka pelajaran dengan mengucapkan salam, serentak siswa pun berdiri dengan membalas salam guru, setelah itu kemudian guru mengamati seluruh siswa dan mengabsen siswa satu per satu agar guru tetap ingat dengan nama-nama siswa dan wajah siswa itu sendiri. Setelah selesai mengabsen siswa kemudian guru mengisi jurnal kelas, dan mulai membuka pelajaran dengan menciptakan suasana kondusif dalam kelas.

Ketika membuka pelajaran nampaknya siswa masih ribut dan kurang memperhatikan gurunya di depan kelas. Melihat kondisi kelas seperti itu, guru berupaya untuk menciptakan suasana kelas agar menarik perhatian siswa. Setelah selesai membacakan standar kompetensi, kompetensi dasar, indikator dan tujuan pembelajaran, selanjutnya guru memberikan apersepsi kepada siswa dengan memberikan pertanyaan seputar materi yang akan diajarkan.

Tanpa basa-basi siswa langsung mengerjakan tugas yang di berikan oleh guru. Nampaknya semua siswa sangat antusias mengerjakan tugas yang diberikan dengan menjadikan buku panduan sebagai rujukan untuk mencari alternatif jawaban. Setelah dirasakan cukup lama siswa belum selesai mengerjakan tugas nampaknya siswa masih sibuk dengan aktivitasnya, maka guru kembali mengingatkan waktu siswa akan segera habis.

Semua siswa terperanjat kaget mendengar waktu sudah habis dan dengan segera, siswa mengakhiri kemudian dilanjutkan dengan kegiatan presentasi. Setelah itu, hasil presentasi dikomentari oleh siswa lain dan dalam kegiatan ini diadakan tanya jawab dan siswa yang presentasi menjawab pertanyaan yang diajukan oleh temannya.

Sebelum mengakhiri pelajaran, guru mengingatkan siswa untuk mempelajari kembali tugas yang sudah didapat di sekolah. Untuk mengantisipasi agar siswa belajar kembali dirumah, maka guru menugaskan siswa untuk mengerjakan latihan tugs yang ada di lembar tugas masing-masing siswa dan dikumpulkan pada pertemuan yang akan datang. Untuk mengakhiri 
pelajaran, guru mengucapkan salam dan siswa dipersilahkan untuk melanjutkan pelajaran berikutnya.

\section{Pertemuan II}

Pertemuan II siklus II dilaksanakan pada hari Senin, 15 Juli 2010 jam pelajaran ke 3 - 6 . Semua siswa kelas VIII 2 hadir pada pertemuan ini.

Kegiatan pembelajaran yang dilakukan pada pertemuan II siklus II ini sama seperti pada pertemuan II namun pelaksanaan kegiatannya agak mengalami sedikit pergeseran waktu. Pada pertemuan II siklus II, ketika memasuki ruang kelas guru mulai membuka pelajaran dengan salam, serentak siswa pun berdiri dan membalas salam guru, setelah kemudian guru mengamati seluruh siswa dan mengabsen siswa satu per satu agar guru tetap ingat dengan nama-nama siswa dan wajah siswa itu sendiri. Setelah selesai mengabsen siswa kemudian guru mengisi jurnal kelas, dan mulai membuka pelajaran dengan menciptakan suasana kondusif dalam kelas.

Setelah selesai membacakan standar kompetensi, kompetensi dasar, indikator dan tujuan pembelajaran, selanjutnya guru memberikan apersepsi kepada siswa dengan mengajukan beberapa pertanyaan dan setelah itu mengaitkannya dengan pelajaran yang akan disampaikan pada pertemuan tersebut. Kemudian banyak siswa yang angkat tangan untuk menjawab pertanyaan, siswa yang ditunjuk pun menjawab dengan benar dan ada juga yang jawabannya agak keliru. Namun guru dengan segera meluruskan jawaban siswa dan mengarahkan siswa agar memperoleh jawaban yang benar.

Setelah memberikan apersepsi, siswa diminta untuk duduk sesuai kelompoknya pada pertemuan sebelumnya. Setelah pembagian kelompok selesai dan siswa sudah duduk sesuai dengan anggota kelompoknya, guru kemudian menjelaskan sedikit tentang materi yang dibahas pada pertemuan tersebut. Setelah guru selesai menjelaskan dan memberikan contoh soal, guru kemudian membagikan LKS yang berisikan latihan-latihan soal yang melibatkan masalah sehari-hari.

Tanpa basa-basi siswa langsung mengerjakan tugas yang di berikan oleh guru. Nampaknya semua siswa sangat antusias mengerjakan tugas yang diberikan. Untuk menjaga agar situasi diskusi tetap tertib, maka guru tidak hanya diam tetapi guru ikut mengawasi kegiatan siswa dengan berkeliling mengawasi kelompok-kelompok berdiskusi. Berbeda dengan kegiatan pada pertemuan pertama siklus II, pada pertemuan kedua siswa agak lebih cepat mengerjakan tugas dengan sisa waktu 10 menit sebelum kegiatan belajar berakhir.

Sebelum mengakhiri pelajaran, guru mengingatkan siswa untuk mempelajari kembali pelajaran yang sudah didapat di sekolah dan pertemuan I dan kedua karena pada pertemuan yang akan datang akan diadakan tes akhir siklus II. Untuk mengakhiri pelajaran, guru mengucapkan salam dan siswa dipersilahkan untuk melanjutkan pelajaran berikutnya.

\section{Pertemuan III}

Pertemuan III siklus II dilaksanakan pada hari Senin, 22 Juli 2010 jam pelajaran ke 3-6. Semua siswa hadir pada pertemuan ini.

Mengawali pertemuan guru mengabsen siswa, mempersiapkan mereka mengikuti pembelajaran, selanjutnya bertanya tentang tugas pada pertemuan sebelumnya. Setelah bertanya tentang kesiapan siswa untuk mengikuti tes akhir, guru pun melanjutkan kegiatan dengan menilai hasil belajar siswa secara individu dengan membagikan tes formatif. 
Sebagian besar siswa dalam mengerjakan tes nampak serius dan mengerjakan dengan sungguh-sungguh. Mengakhiri kegiatan penilaian, guru menutup pelajaran dengan mengucapkan salam kepada siswa.

\section{Hasil Tindakan Sikius II}

Hasil tes akhir siklus II menunjukkan bahwa kemampuan siswa dalam menjawab tes hasilnya mengalami pen peningkatan yang sangat drastis, Hasil tes akhir menunjukkan bahwa siswa yang sudah tuntas. Nilai yang diperoleh siswa sudah tergolong tinggi. Secara rinci hasil tes akhir pada siklus II diuraikan pada tabel berikut ini.

Tabel 3. Data Tes Hasil Belajar Siswa pada Siklus II

\begin{tabular}{|c|c|c|c|c|c|}
\hline No. & $\begin{array}{r}\text { Nilai } \\
\text { Tes }\end{array}$ & Frekuensi & $\begin{array}{r}\text { Jumlah } \\
\text { Nilai }\end{array}$ & No. Absen & Ket \\
\hline 1 & 70 & 2 & 140 & 17,21 & $\mathrm{~T}$ \\
\hline 2 & 75 & 1 & 75 & 23 & $T$ \\
\hline 3 & 80 & 3 & 240 & $1,27,31$ & $T$ \\
\hline 4 & 85 & & & & $\mathrm{~T}$ \\
\hline 5 & 90 & 14 & 1260 & $\begin{array}{l}3,6,11,12,13,15,20 \\
22,24,25,28,29,30,32\end{array}$ & $\mathrm{~T}$ \\
\hline 6 & 95 & 2 & 190 & 5,8 & $\mathrm{~T}$ \\
\hline \multirow[t]{2}{*}{7} & 100 & 10 & 1000 & $\begin{array}{l}2,4,7,9,10,14,16,18 \\
19,26\end{array}$ & $\mathrm{~T}$ \\
\hline & $\mathrm{N}$ & 32 & & & \\
\hline$\sum x$ & & & 2905 & & \\
\hline Rata- & & & 90,78 & & \\
\hline Daya & & & $90,78 \%$ & & \\
\hline Ketu & & & $100 \%$ & & \\
\hline
\end{tabular}

Keterangan:

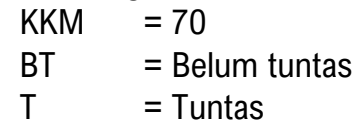

Secara klasikal ketuntasan belajar siswa kelas VIII 2 SMP Negeri 3 Palopo Kota Palopo pada siklus II adalah 100\%. Hal ini menunjukkan bahwa ketuntasan belajar siswa sudah mencapai kriteria keberhasilan yaitu dengan ketuntasan minimal $70 \%$. Rata-rata hasil belajar siswa secara klasikal 90,78\% sudah mencapai hasil yang diharapkan yaitu dengan KKM 70. Daya serap siswa mencapai $90,78 \%$ yang berada pada kategori tinggi (berdasarkan tabel konversi). Hasil belajar yang dicapai oleh siswa bisa dikatan sudah sangat baik.

\section{Refleksi Siklus II}

Berdasarkan data hasil belajar di atas jika dibandingkan dengan hasil tes akhir siklus I dapat dijelaskan bahwa pada siklus II ini semua siswa nilainya sudah meningkat drastis, semua siswa $(100 \%)$ nilainya sudah tuntas. Nilai tertinggi yang dicapai yaitu 100 dan terendah 70 .

Untuk mendapat gambaran lebih jelas tentang adanya peningkatan kemampuan, daya serap, dan ketuntasan hasil belajar pada tes awal dan tes akhir baik itu pada siklus I maupun siklus II, maka ditampilkan ringkasannya pada tabel berikut: 
Tabel 4. Ringkasan Analisis Data Tes Awal dengan Tes Akhir Siklus I — II

\begin{tabular}{|c|c|c|c|c|c|c|c|c|}
\hline \multirow{3}{*}{ No. } & \multirow{3}{*}{$\begin{array}{l}\text { Nilai } \\
\text { Tes }\end{array}$} & \multicolumn{2}{|c|}{ Tes Awal } & \multicolumn{4}{|c|}{ Tes Akhir } & \multirow[t]{3}{*}{ Ket. } \\
\hline & & \multirow[b]{2}{*}{ Frekuensi } & \multirow{2}{*}{$\begin{array}{c}\text { Jumlah } \\
\text { Nilai }\end{array}$} & \multicolumn{2}{|c|}{ Siklus I } & \multicolumn{2}{|c|}{ Siklus II } & \\
\hline & & & & Frekuensi & $\begin{array}{c}\text { Jumlah } \\
\text { Nilai }\end{array}$ & Frekuensi & $\begin{array}{c}\text { Jumlah } \\
\text { Nilai }\end{array}$ & \\
\hline 1 & 30 & 1 & 30 & - & - & - & - & BT \\
\hline 2 & 40 & 4 & 160 & - & - & - & - & BT \\
\hline 3 & 45 & - & - & - & - & - & - & BT \\
\hline 4 & 50 & 11 & 550 & - & - & - & - & BT \\
\hline 5 & 55 & - & - & - & - & - & - & BT \\
\hline 6 & 60 & 6 & 360 & - & - & - & - & $\mathrm{T}$ \\
\hline 7 & 65 & - & - & - & - & - & - & $\mathrm{T}$ \\
\hline 8 & 70 & 8 & 560 & 15 & 1050 & 2 & 140 & $\mathrm{~T}$ \\
\hline 9 & 75 & - & - & 9 & 675 & 1 & 75 & $\mathrm{~T}$ \\
\hline 10 & 80 & 2 & 160 & 7 & 560 & 3 & 240 & $\mathrm{~T}$ \\
\hline 11 & 85 & - & - & 1 & 85 & - & - & $\mathrm{T}$ \\
\hline 12 & 90 & - & - & - & - & 14 & 260 & $\mathrm{~T}$ \\
\hline 13 & 95 & - & - & - & - & 2 & 190 & $\mathrm{~T}$ \\
\hline \multirow[t]{2}{*}{14} & 100 & - & - & - & - & 10 & 1000 & $\mathrm{~T}$ \\
\hline & $\mathrm{N}$ & 32 & & 32 & & 32 & & \\
\hline$\sum x$ & & & 1820 & & 2370 & & 2905 & \\
\hline \multicolumn{2}{|c|}{ Rata-rata kela } & las & 56,88 & & 74,06 & & 90,75 & \\
\hline \multicolumn{2}{|c|}{ Daya serap (\% } & $(\%)$ & $56,88 \%$ & & $74,06 \%$ & & $90,75 \%$ & \\
\hline \multicolumn{2}{|c|}{ Ketuntasan (\% } & $(\%)$ & $31,25 \%$ & & $100 \%$ & & $100 \%$ & \\
\hline
\end{tabular}

Adanya peningkatan rata-rata, daya serap, dan ketuntasan prestasi belajar pada tes awal dan tes akhir baik itu pada siklus I maupun siklus II juga dapat diamati pada grafik berikut ini.

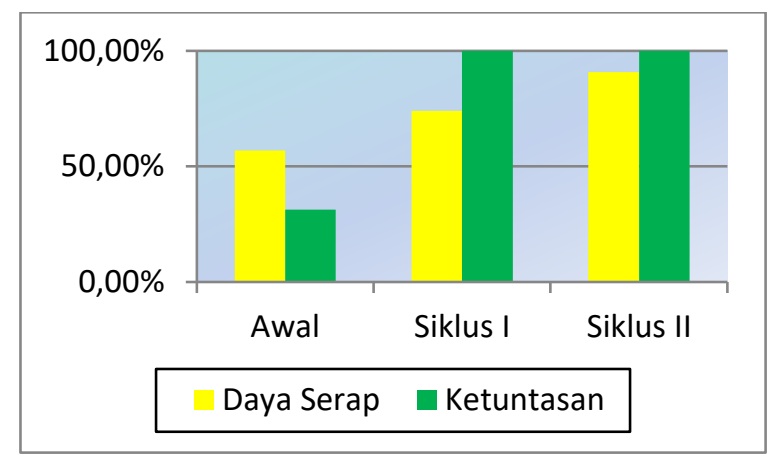

Gambar 1. Daya serap dan ketuntasan belajar tes awal dengan tes akhir pada siklus I - II

Berdasarkan ringkasan analisis data tes awal sampai dengan tes akhir baik itu pada siklus I dan siklus II seperti tercantum pada tabel diatas menunjukkan peningkatan rata-rata kelas, daya serap siswa, dan ketuntasan pada akhir siklus II dalam penelitian ini dapat diterima dan berarti implementasi model pembelajaran pemberian tugas dapat meningkatkan hasil belajar siswa kelas VIII SMP Negeri 3 Palopo Kota Palopo.

Berdasarkan data tersebut dapat dikatakan bahwa penelitian ini berhasil karena siswa mengalami peningkatan. Sesuai dengan hasil analisis, nilai rata-rata kelas mengalami peningkatan dari 74,06 menjadi 90,75 , daya serap mengalami peningkatan dari $74,06 \%$ menjadi $90,75 \%$ dan ketuntasan terjadi secara maksimal sebesar $100 \%$ pada siklus I dan II. Peningkatan ini menunjukkan bahwa model pembelajaran dengan tugas dapat meningkatkan hasil belajar siswa pada kelas VIII SMP Negeri 3 Palopo Kota Palopo. 


\section{Kesimpulan}

Penerapan metode pemberian tugas dalam penelitian ini menunjukkan perubahan pada siswa yang ditandai dengan meningkatnya penguasaan materi mata pelajaran Keterampilan (Seni Rupa) hal ini hal ini dapat dilihat dan skor tes penguasaan materi siswa pada setiap akhir siklus mengalami peningkatan serta aktivitas siswa yang ditunjukkan dalam proses belajar mengajar mengarah ke perubahan yang lebih baik atau positif.

Berdasarkan hasil penelitian dan pembahasan yang telah diuraikan sebelumnya mulai dari awal penelitian sampai berakhirnya penelitian ini. maka dapat ditarik kesimpulan bahwa metode pemberian tugas dapat meningkatkan prestasi belajar siswa.

Dalam upaya meningkatkan kemampuan penguasaan materi mata pelajaran keterampilan (seni rupa), disarankan agar para guru studi produktif yang lain agar dapat menerapkan metode pemberian tugas dalam pembelajaran. Selain itu, pihak sekolah, diharapkan memfasilitasi bantuan alat - alat bantu menggambar yang sepenuhnya kepada guru dalam upaya meningkatkan prestasi belajar para siswa.

\section{Referensi}

Arikunto, S., Shuardjono, \& Supriadi. (2006). Penelitian Tindakan Kelas. Jakarta: PT. Bumi Aksara.

Haling, A. (2007). Belajar dan Pembelajaran. Makassar; Badan Penerbit UNM.

Herwono. (2005). Menjadi Guru yang Mau dan Mampu Mengajar dengan Menggunakan Pendekatan Kontestual. Bandung: MLC.

Maman. (2006). Penelitian Tindakan Kelas. Fakultas Teknik UNM. Program Peningkatan Kualifikasi Guru SMP.

Mulyasa. (2008). Menjadi Guru Profesional, Menciptakan Pembelajaran Kreatif dan Menyenangkan. Bandung: PT. Remaja Rodakarya.

Nurhadi. (2004). Kurikulum 2004. (Pertanyaan dan Jawaban). Jakarta; PT. Gramedia Widiasaran Indonesia.

Wiriaatmadja, R. (2005). Metode Penelitian Tindakan Kelas. Bandung: PT. Remaja Rosdakarya. 